$\rightarrow$ DOI : $10.15740 / \mathrm{HAS} / \mathrm{AJBS} / 12.2 / 51-78$

e ISSN-0976-8343 | Visit us : www.researchjournal.co.in
ASIAN JOURNAL OF BIO SCIENCE

Volume 12 | Issue 2 | Oct., 2017 | 51-78

\author{
RESEARCHPAPER
}

\title{
Nitrogen management in maize based legume intercropping system
}

\author{
ROHIT KUMAR ${ }^{1}$ DEVENDRA SINGH ${ }^{1}$ AND BHANWAR LAL JAT ${ }^{2}$
}

${ }^{1}$ Department of Agriculture, Bhagwant University, AJMER (RAJASTHAN) INDIA

${ }^{2}$ Department of Agricultural Biotechnology, Bhagwant University, AJMER (RAJASTHAN) INDIA

Email : rohitsharmaranker@gmail.com

Article Info : Received : 16.05.2017; Revised : 05.08.2017; Accepted : 02.09.2017

The experiment consisting of 2 intercropping patterns, 3 methods of fertilizer application, 2 nitrogen doses in maize along with 2 sole crop treatments in $\mathrm{n}+2$ Factorial Randomized Block Design with three replications was conducted at Bhagwant University during the Kharif 2016. The results revealed that planting patterns remained statistically equal with respect to cob yield, grain yield and yield attributes viz., cob length, cob girth and number of grain rows per cob, number of grains per row and number of grains per cob. Furrow application of fertilizers recorded significantly higher cob length, higher number of grains per cob, number of grain per row, cob yield and grain yield than broadcast but remained at par with side placement. Between nitrogen doses, 100 per cent recommended nitrogen recorded significantly higher cob length, number of grains per row, number of grain per cob, cob yield and grain yields than 75 per cent. Significantly more grain yield of intercropped urdbean was obtained in under paired row planting method than normal planting. Grain yield of urdbean did not vary significantly due to $\mathrm{N}$ fertilization and different methods of fertilizer application in maize. Maize grain equivalent yield was found significantly higher in paired row system than normal planting. Different methods of fertilizer application and $\mathrm{N}$ dose did not produce significant variations in MGEY. Intercropping of maize showed significantly more MGEY than sole cropping. Intercropping of urdbean in between paired row maize gave significantly higher gross and net returns than normal planting. Method of fertilizer application and dose of nitrogen did not cause significant variation in monetary advantage. Maize may be fertilized with 75 per cent recommended dose of nitrogen in association with legumes. Furrow placement of fertilizers is superior to other methods.

Key words : DAP, DAS, LAI, RBD, MGEY

How to cite this paper : Kumar, Rohit, Singh, Devendra and Jat, Bhanwar Lal (2017). Nitrogen management in maize based legume intercropping system. Asian J. Bio. Sci., 12 (2) : 51-78.DOI : 10.15740/HAS/AJBS/12.2/51-78. 